\title{
Bioefficacy of Essential Oils and Plant Oils for the Management of Banana Anthracnose-A Major Post-harvest Disease
}

\author{
Divya Jagana*, Yashoda R. Hegde and Rajasekhar Lella
}

Department of Plant Pathology, College of Agriculture, University of Agricultural Sciences, Dharwad - 580005, Karnataka, India

*Corresponding author

\section{A B S T R A C T}

\section{Keywords}

Essential oil, Plant oils,

Banana anthracnose,

Colletotrichum musae,

Disease reduction

Article Info

Accepted:

20 March 2018

Available Online:

10 April 2018
Antifungal activity of essential oils needs to be appreciated in the management of plant diseases for their biodegradable, economical and ecofriendly nature. Anthracnose of banana is caused by Colletotrichum musae and is one of the most serious diseases of ripe banana. Present investigation was carried out during 2016 in department of plant pathology, UAS, Dharwad aimed on ecofriendly management of banana anthracnose by essential oils in vitro as well as in vivo. Out of five oils evaluated in vitro against $C$. musae, complete inhibition of mycelial growth was reported in vitro with clove oil at all the concentrations tested $(0.5,1.0$ and $2.0 \%)$ and eucalyptus oil at 2.0 per cent concentration. However, the most effective postharvest dip treatments in vivo were lemongrass oil at 2.0 and 1.0 per cent and neem oil at 2.0 per cent eucalyptus, neem oil at 2.0 per cent and neem oil at 1.0 per cent concentration. We conclude this study revealing that lemongrass oil even at $1.0 \%$ concentration found most effective postharvest treatment for against antracnose without phytotoxicity effect on fruits.

\section{Introduction}

Quality of tropical fruits is commonly affected by post-harvest disease such as fruit rot mostly caused by improper handling and storage, during transportation and marketing. Anthracnose of banana is caused by Colletotrichum musae and is one of the most serious diseases of ripe banana. The first step to control fruit rots involves use of chemical fungicide in field and storage however, indiscriminate use of synthetic fungicides has been a major cause for development of resistant fungal strains, increased amounts of toxic residues in food products. Although alternative methods are being researched for the management of postharvest fruit rots, natural plant products such as essential oils are gaining popularity and drawing attention of researchers global wide owing to their biodegradable, economical and eco-friendly nature. The essential oils of different plant origin have been reported fungicidal properties in vitro as well as in vivo studies. They are safe for environment and many of them are currently in use, are approved by the FDA as flavouring agents in food industry. The general antifungal activity of essential oils is well documented (Meepagala et al., 2002) and there have been some studies on the 
effects of essential oils on postharvest pathogens. The advantage of essential oils is their bioactivity in the vapour phase, a characteristic that makes them attractive as possible fumigants for stored product protection.

In the recent years, there has been major thrust on residue free, organic fruit production. In view of this present study aimed to evaluate few essential oils for the management of Anthracnose, major postharvest disease of banana.

\section{Materials and Methods}

The present investigations pertaining to management of postharvest disease of banana were carried out during 2016 in the Department of Plant Pathology, College of Agriculture, University of Agricultural Sciences, Dharwad, Karnataka. Banana fruits showing characteristic symptoms of anthracnose disease were used for isolation of pathogens following standard tissue isolation procedure to obtain the pure culture of Colletotrichum musae on potato dextrose agar. Essential oils were selected for this investigation whose antifungal properties were well documented by earlier researchers in various crops. Oils were procured from local market, Dharwad and evaluated at three concentrations $(0.5,1.0$ and $2.0 \% \mathrm{v} / \mathrm{v}) \mathrm{viz}-$ Clove bud oil [Syzygium aromaticum (L) Merr. Et Perry], Eucalyptus oil [Eucalyptus globules Labill.], Lemongrass oil [Cymbopogan citrates Stapf.], Castor oil [Ricinus communis L.] Neem oil [Azadirachta indica A. Juss]. Fully matured unripe banana were procured from primary wholesalers for experimentation.

\section{In vitro evaluation of oils}

Required quantity of individual oils was added separately into molten and cooled potato dextrose agar so as to get the desired concentration in $100 \mathrm{ml}$ final volume of media. Later $20 \mathrm{ml}$ of the poisoned medium was poured into sterile Petriplates. Fungal discs of five $\mathrm{mm}$ size from actively growing culture of the fungus were cut out by a sterile cork borer and one such disc was placed at the centre of each agar plate. Each treatment was replicated thrice. Control was maintained by growing the pathogen on PDA plates. Inoculated plates were incubated at room temperature and radial colony growth was measured as explained earlier. The efficacy of oils was expressed as per cent inhibition of mycelial growth over control that was calculated by using the formula suggested by Vincent (1947).

\section{In vivo evaluation of oils}

Five oils were evaluated under in vivo conditions at three concentrations $(0.5,1.0$ and $2.0 \% \mathrm{v} / \mathrm{v})$. Fruits selected for in vivo studies were at mature green stage, free from blemishes and injuries. Banana fingers with intact crown portion were sterilized in 1.0 per cent sodium hypochlorite and rinsed with sterilized distilled water. These fingers were dipped in postharvest treatment solutions prepared from oils of required concentration which were for ten min and allowed to dry in aseptic chamber. These fruits were dipped in spore suspension of $C$. musae $\left(1 \times 10^{5}\right)$ for one min and allowed to dry aseptically. The fingers dipped in sterilized water for ten min followed by spore suspension of $C$. musae $\left(1 \times 10^{5}\right)$ served as untreated control. Cotton swabs dipped in sterile water were placed in moist chamber to maintain sufficient humidity during incubation. Observations were recorded on per cent area infected on fruit in 0-5 scale after eight days of inoculation. Per cent disease index was computed by using the formula given by Wheeler (1969) and analysed statistically. Per cent disease reduction in different treatments over control 
was derived by using the formula suggested by Vincent (1947).

\section{Statistical analysis}

The experiment was laid out in a completely randomized design (CRD) with a factorial combination of treatments in different concentrations in three replications. The experiment was conducted at room temperature in the laboratory. Statistical analysis was done as per the procedures given by Gomez and Gomez (1984). All comparisons of means were subjected to analysis of variance (ANOVA) and the significant differences among treatments were determined with a least significant difference (lsd) separation test. Arcsine or square root transformation was used where ever required to normalize variance.

\section{Results and Discussion}

\section{In vitro evaluation of oils}

In the quest of bioefficacious, economic and environmental friendly alternative to postharvest pathogens, the essential oils can be ideal candidates for use as agrochemicals (Macias et al., 2002). Most of the essential oils have been reported to inhibit postharvest fungi in laboratory conditions (Bellerbeck et al., 2001; Hidalgo et al., 2002) (Table 1).

Present study carried out to evaluate five oils against C. musae (Fig. 1) revealed that, complete inhibition of fungal growth was reported with clove oil at all the concentrations tested $(0.5,1.0$ and $2.0 \%)$ and eucalyptus oil at 2.0 per cent concentration which were statistically on par and found significant over all the treatments. Next best treatment was lemongrass oil at 2.0 per cent concentration $(73.74 \%)$. In agreement with current findings, several studies reported antifungal activity of essential oils against postharvest fungi; Win et al.,(2007) reported antifungal activities of cinnamon extract, piper extract and garlic extract on banana crown rot fungi under in vitro evaluation ( $C$. musae, Fusarium spp. and L. theobromae). In another study, Abd-AllA et al., (2013) reported antifungal activity of four essential oils under in vitro condition against $C$. gloeosporioides causing mango anthracnose. Similarly, Lambat et al., (2004) had also reported that lemongrass oil at 0.2-0.6 per cent and eucalyptus oil at 1.5-3.0 per cent possessed broad-spectrum antifungal activities against seven plant pathogens (Table 2).

Table.1 In vitro evaluation of oils on mycelial growth of Colletotrichum musae

\begin{tabular}{|c|c|c|c|c|}
\hline \multirow[t]{3}{*}{ Oils } & \multicolumn{3}{|c|}{ Per cent inhibition of mycelial growth } & \multirow[t]{3}{*}{ Mean } \\
\hline & \multicolumn{3}{|c|}{ At concentrations $(\%)$} & \\
\hline & 0.5 & 1.0 & 2.0 & \\
\hline Castor & $3.48(10.76) *$ & $46.77(43.15)$ & $47.96(43.83)$ & $32.74(34.90)$ \\
\hline Clove & $100.00(90.00)$ & $100.00(90.00)$ & $100.00(90.00)$ & $100.00(90.00)$ \\
\hline Eucalyptus & $49.48(44.70)$ & $69.32(56.37)$ & $100.00(90.00)$ & $72.93(58.65)$ \\
\hline Lemongrass & $51.67(45.96)$ & $67.47(55.22)$ & $73.74(59.17)$ & $64.29(53.30)$ \\
\hline Neem oil & $37.13(37.54)$ & $40.09(39.29)$ & $52.59(46.49)$ & $43.27(41.13)$ \\
\hline Mean & $48.35(44.06)$ & $64.73(53.57)$ & $73.86(59.91)$ & \\
\hline Source & \multicolumn{2}{|l|}{ S.E $\mathbf{m} \pm$} & \multicolumn{2}{|l|}{ CD at $1 \%$} \\
\hline Treatment (T) & \multicolumn{2}{|l|}{0.25} & \multicolumn{2}{|l|}{0.97} \\
\hline Concentration $(\mathrm{C})$ & \multicolumn{2}{|l|}{0.19} & \multicolumn{2}{|l|}{0.75} \\
\hline $\mathbf{T} \times \mathbf{C}$ & \multicolumn{2}{|l|}{0.43} & \multicolumn{2}{|l|}{1.67} \\
\hline
\end{tabular}

*Arcsine transformed values 
Table.2 Bioefficacy of oils for the management of banana anthracnose

\begin{tabular}{|c|c|c|c|c|c|c|c|c|}
\hline \multirow[t]{3}{*}{ Oils } & \multicolumn{4}{|c|}{ Per cent disease index } & \multicolumn{4}{|c|}{ Per cent disease reduction over control } \\
\hline & \multicolumn{4}{|c|}{ At concentrations $(\%)$} & \multicolumn{4}{|c|}{ At concentrations $(\%)$} \\
\hline & 0.5 & 1.0 & 2.0 & Mean & 0.5 & 1.0 & 2.0 & Mean \\
\hline Castor oil & $\begin{array}{l}42.22 \\
(40.52)^{*}\end{array}$ & $\begin{array}{l}31.11 \\
(33.90)\end{array}$ & $\begin{array}{l}15.56 \\
(23.23)\end{array}$ & $\begin{array}{l}29.63 \\
(32.98)\end{array}$ & $\begin{array}{l}48.65 \\
(44.22)\end{array}$ & $\begin{array}{l}62.16 \\
(52.06)\end{array}$ & $\begin{array}{l}81.08 \\
(64.32)\end{array}$ & $\begin{array}{l}63.96 \\
(53.53)\end{array}$ \\
\hline Clove oil & $\begin{array}{l}26.67 \\
(31.09)\end{array}$ & $\begin{array}{l}17.78 \\
(24.94)\end{array}$ & $\begin{array}{l}15.56 \\
(23.23)\end{array}$ & $\begin{array}{l}20.00 \\
(26.57)\end{array}$ & $\begin{array}{l}67.57 \\
(55.28)\end{array}$ & $\begin{array}{l}78.38 \\
(62.38)\end{array}$ & $\begin{array}{l}81.08 \\
(64.32)\end{array}$ & $\begin{array}{l}75.68 \\
(60.66)\end{array}$ \\
\hline Eucalyptus oil & $\begin{array}{l}22.22 \\
(28.12)\end{array}$ & $\begin{array}{l}15.56 \\
(23.23)\end{array}$ & $\begin{array}{l}8.89 \\
(17.35)\end{array}$ & $\begin{array}{l}15.56 \\
(23.23)\end{array}$ & $\begin{array}{l}72.97 \\
(58.73)\end{array}$ & $\begin{array}{l}81.08 \\
(64.32)\end{array}$ & $\begin{array}{l}89.19 \\
(71.06)\end{array}$ & $\begin{array}{l}81.08 \\
(64.70)\end{array}$ \\
\hline Lemongrass oil & $\begin{array}{l}11.11 \\
(19.47)\end{array}$ & $\begin{array}{l}6.67 \\
(14.97)\end{array}$ & $\begin{array}{l}6.67 \\
(14.97)\end{array}$ & $\begin{array}{l}8.15 \\
(16.59)\end{array}$ & $\begin{array}{l}86.48 \\
(68.65)\end{array}$ & $\begin{array}{l}91.89 \\
(73.46)\end{array}$ & $\begin{array}{l}91.89 \\
(73.46)\end{array}$ & $\begin{array}{l}90.09 \\
(71.85)\end{array}$ \\
\hline Neem oil & $\begin{array}{l}13.33 \\
(21.41)\end{array}$ & $\begin{array}{l}8.89 \\
(17.35)\end{array}$ & $\begin{array}{l}6.67 \\
(14.97)\end{array}$ & $\begin{array}{l}9.63 \\
(18.08)\end{array}$ & $\begin{array}{l}83.78 \\
(66.25)\end{array}$ & $\begin{array}{l}89.19 \\
(71.06)\end{array}$ & $\begin{array}{l}91.89 \\
(73.46)\end{array}$ & $\begin{array}{l}88.29 \\
(70.25)\end{array}$ \\
\hline Untreated control & & & & $\begin{array}{l}82.23 \\
(65.06)\end{array}$ & & & & \\
\hline Source & \multicolumn{2}{|l|}{ S.E $\mathbf{m} \pm$} & \multicolumn{2}{|c|}{ CD at $5 \%$} & \multicolumn{2}{|l|}{ S.E $\mathbf{m} \pm$} & \multicolumn{2}{|c|}{ CD at $5 \%$} \\
\hline Treatment $(\mathbf{T})$ & \multicolumn{2}{|l|}{0.65} & \multicolumn{2}{|c|}{1.87} & \multicolumn{2}{|l|}{0.95} & \multicolumn{2}{|c|}{2.73} \\
\hline Concentration (C) & \multicolumn{2}{|l|}{0.84} & \multicolumn{2}{|l|}{2.42} & \multicolumn{2}{|l|}{0.73} & \multicolumn{2}{|l|}{2.12} \\
\hline $\mathbf{T} \times \mathbf{C}$ & \multicolumn{2}{|l|}{1.45} & \multicolumn{2}{|l|}{4.18} & \multicolumn{2}{|l|}{1.64} & \multicolumn{2}{|l|}{4.73} \\
\hline
\end{tabular}

*Arcsine transformed values

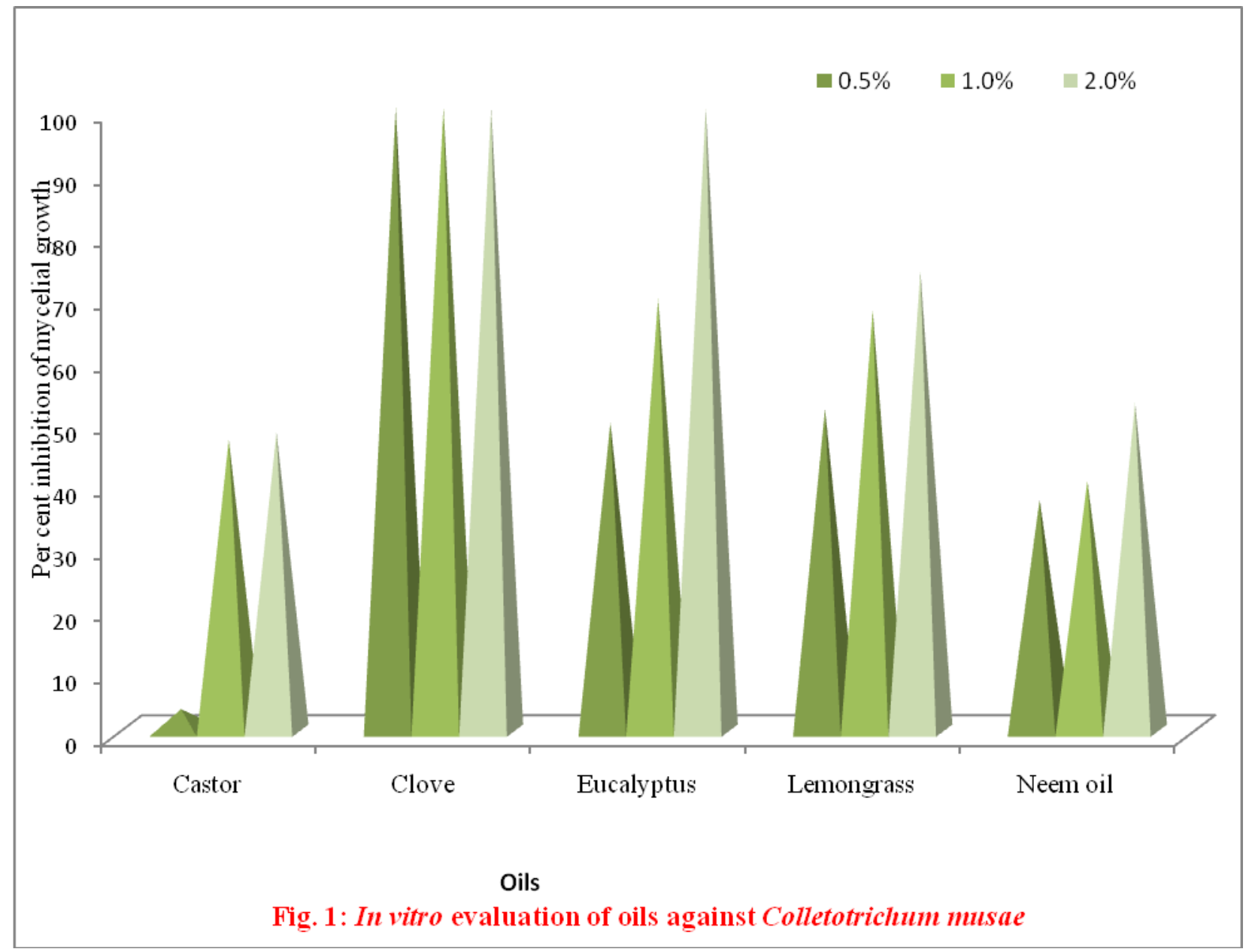



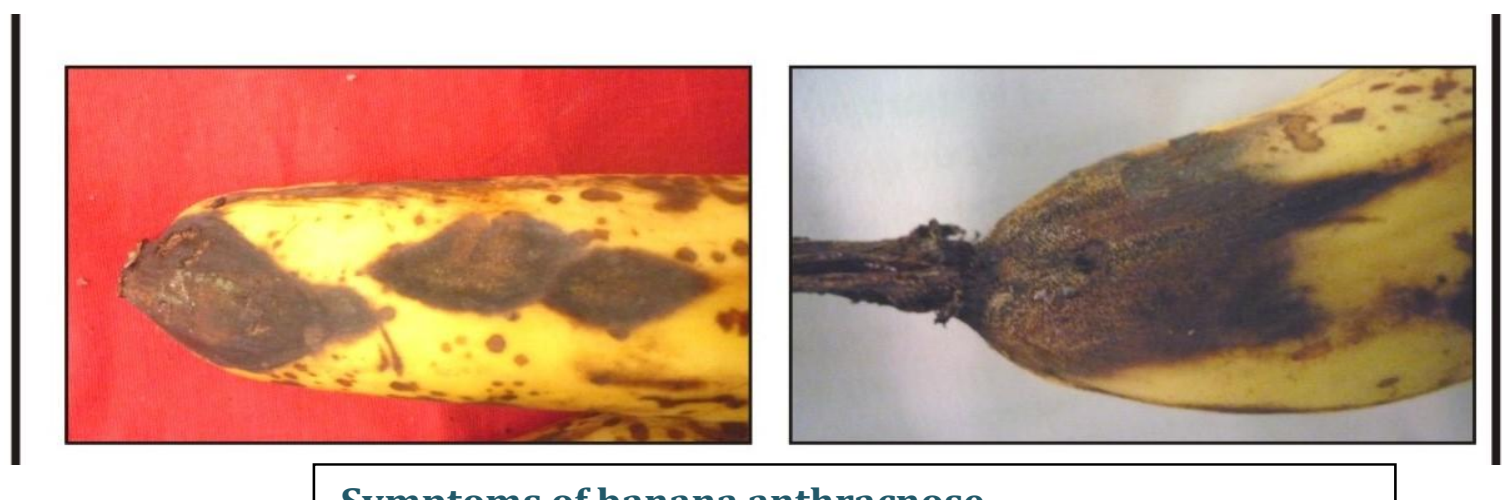

Symptoms of banana anthracnose

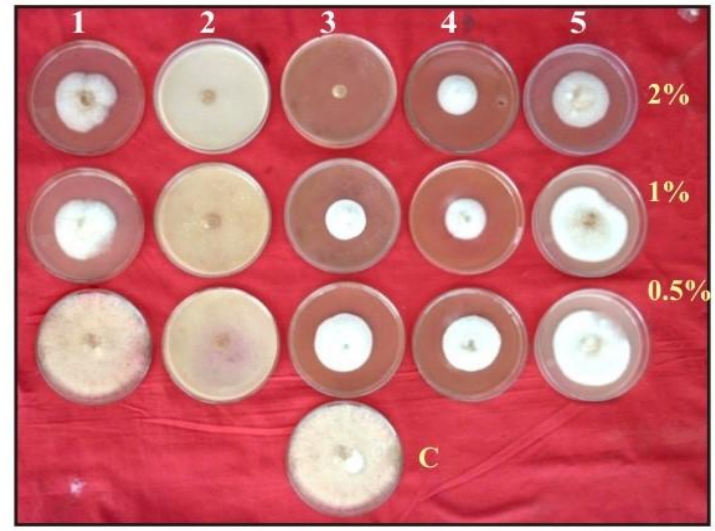

1. Castor oil

2. Clove oil

3. Eucalyptus oil

4. Lemongrass oil

5. Neem oil

C. Control

In vitro evaluation of oils against Colletotrichum

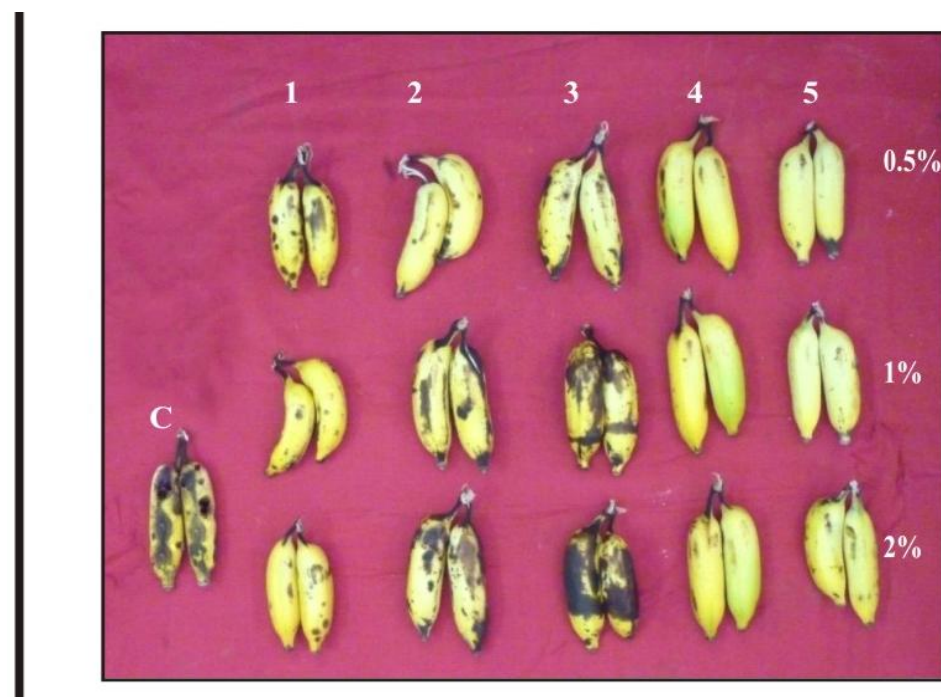

1. Castor oil

2. Clove oil

3. Eucalyptus oil

4. Lemongrass oil

5. Neem oil

C. Control

In vivo evaluation of oils against anthracnose 


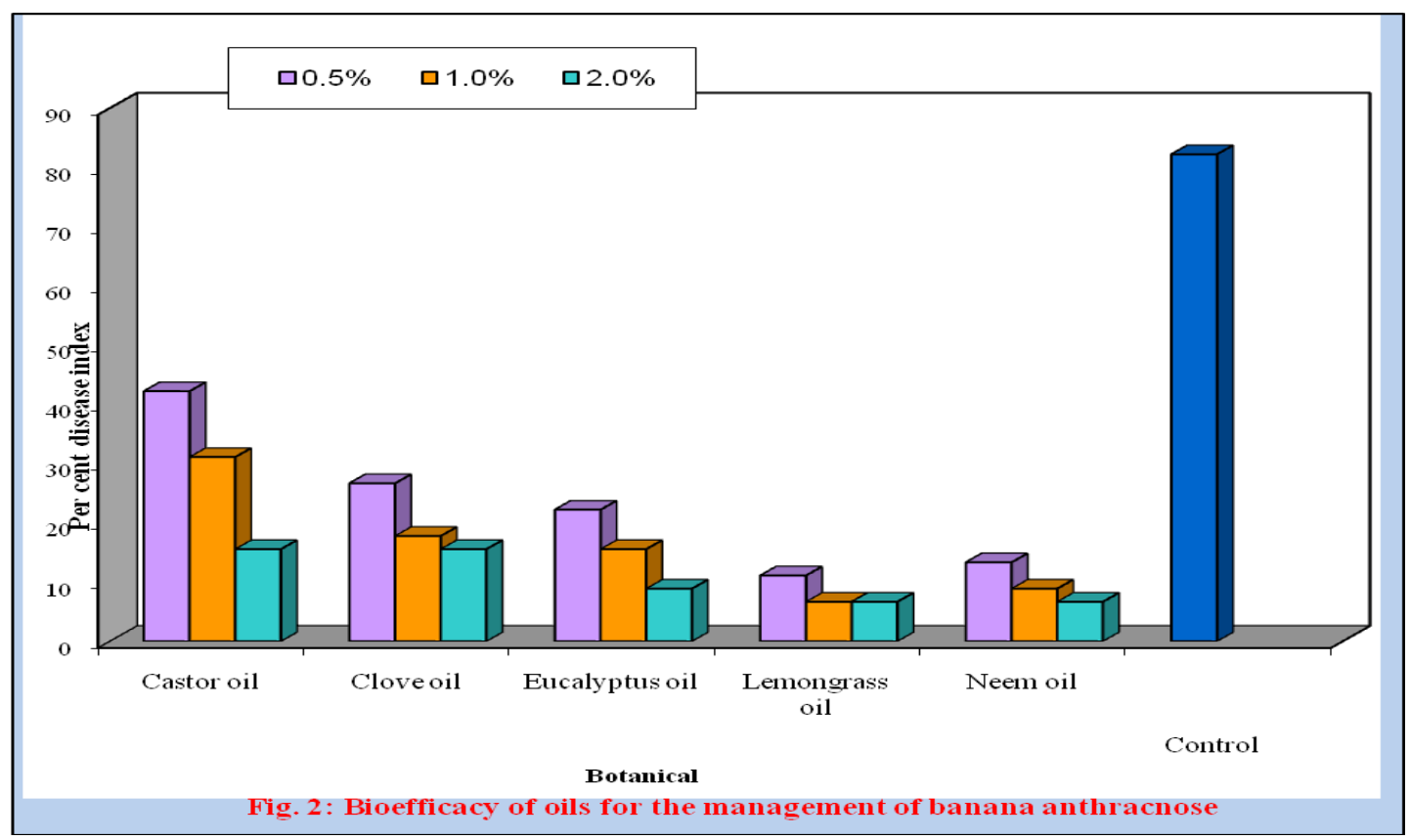

\section{In vivo evaluation of oils}

The advantage of essential oils is their bioactivity in the vapour phase, a characteristic that makes them attractive as possible fumigants for stored product protection. There are also some reports on essential oils in enhancing storage life of fruit and vegetables by controlling their fungal rotting.

All the oils were found to be significant in their efficacy to reduce disease severity in this study (Fig. 2). Out of five oils evaluated against anthracnose, the most effective treatments were lemongrass oil at 2.0 and 1.0 per cent concentration and neem oil which exhibited a disease reduction of 91.89 per cent. These were on par with eucalyptus and neem oil at 2.0 per cent and neem oil at 1.0 per cent which reduced the disease incidence by 89.19 per cent. The reduction of rot severity might be due to the reduction in activity of cell wall degrading enzymes produced by the pathogen. Results clearly indicated that lemongrass oil successfully reduced the disease severity by more than 85 per cent at all the concentrations tested and the treated fruits appeared shiny and with extended shelf life at room temperature. Efficacy of lemongrass oil may be attributed to its broad-spectrum antifungal activities due to the presence of active principle like decanol, dodecanal and dedecanol (Anaruma et al., 2010). Results obtained in present study are in conformity with findings of Ranasinghe et al., (2002) who suggested clove and cinnamon essential oils as alternative postharvest treatments for banana anthracnose. Meanwhile in another study by Sangeetha et al., (2010), treatment of banana fruit variety Robusta (Cavendish) with oils of lemongrass and tulasi had not only reduced the crown rot severity significantly, but also increased the shelf life of banana fruits. The potential of using essential oils by spraying or dipping to control postharvest decay has been examined in fruit and vegetables (Dixit et al., 1995). Further it was observed in present study that eucalyptus oil at higher doses although found effective, caused brown discolouration on fruits. Reasons behind the phytotoxicity were not understood.

Out of five oils evaluated in vitro against $C$. musae, complete inhibition of mycelial growth was reported in vitro with clove oil at all the concentrations tested $(0.5,1.0$ and $2.0 \%)$ and eucalyptus oil at 2.0 per cent concentration, the most effective treatments in vivo were lemongrass oil at 2.0 and 1.0 per cent and neem 
oil at 2.0 per cent eucalyptus, neem oil at 2.0 per cent and neem oil at 1.0 per cent concentration.

\section{References}

Abd-AllA, M. A. and Haggag, W. M. 2013. Use of some plant essential oils as postharvest botanical fungicides in the management of anthracnose disease of mango fruits (Mangifera indica L.) caused by Colletotrichum gloeosporioides (Penz). Inter. J. Agric. Forest., 3(1): 1-6.

Anaruma, N. D., Schmidt, F. L., Durate, M. C. T., Figueira, G. M., Delarmelina, C., Benato, E. A. and Sartoratto, A. 2010. Control of Colletotrichum gloeosporioides (Penz.) Sacc. In yellow passion fruit using Cymbopogon citrates essential oil. Brazilian J. Microbiol., 41: 740-758.

Bellerbeck, V. G., De Roques, C. G., Bessiere, J. M., Fonvieille, J. L. and Dargent, R., 2001. Effect of Cymbopogon nardus (L) W. Watson essential oil on the growth and morphogenesis of Aspergillus niger. Canadian J. Microbio., 47: 9-17.

Dixit, S. N., Chandra, H., Tiwari, R. and Dixit, V., 1995. Development of botanical fungicide against blue mold of mandarins. J. Stored Prod. Res., 31: 165-172.

Gomez, K. A., and Gomez, A. A, 1984. Statistical Procedure for Agricultural Research. Wiley, New York, p. 78-85.

Hidalgo, P. J., Ubera, J. L., Santos, J. A., LaFont, F., Castelanos, C., Palomino, A. and Roman, M., 2002. Essential oils in Culamintha sylvatica wild and cultivated productions and antifungal activity. $J$. Essen. Oil Res., 14: 68-71.
Lambat, P., Zore, G. B., Surwase, B. S. and Karuppayil, S. M., 2004. Broad spectrum of antifungal activity of essential oils from lemongrass and eucalyptus. $J$. Mycol. Pl. Pathol., 34: 545-547.

Macias, F. A., Varela, R. M., Torres, A., Galindo, J. L. G., Molinillo, J. M. G., Inderjit and Mallik, A. U., 2002. Allelochemicals from sunflowers: Chemistry, bioactivity and applications. Chem. Ecology of Plants: Allelopahty in Aquatic and Terrestrial Ecosystem, 7387.

Meepagala, K. M., Sturtz, G. and Wedge, D. E., 2002. Antifungal constituents of the essential oil fraction of Artemisia drancunculus L. var. dracunculus. J. Agril. Food Chem., 50: 6989-6992.

Ranasinghe, L., Jayawardena, B. and Abeywickrama, K., 2002. Fungicidal activity of essential oils of Cinnamomum zeylanicum (L.) and Syzygium aromaticum (L.) Merr et L.M. Perry against crown rot and anthracnose pathogens isolated from banana. Lett. Appl. Microbiol., 35: 208-211.

Sangeetha, G., Thangavelu, R. and Usharani, S., 2010. Evaluation of plant oils for suppression of crown rot disease and improvement of shelf life of banana (Musa spp. AAA subgroup) cv. Robusta. Inter. J. Food Sci. Technol., 45: 10241032.

Vincent, J. M., 1947. Distortion of fungal hyphae in presence of certain inhibitors. Nature, 159: 239-241.

Wheeler, B. E. J., 1969. An Introduction to Plant Diseases. John Willey and Sons Ltd., London, p. 301.

\section{How to cite this article:}

Divya Jagana, Yashoda R. Hegde and Rajasekhar Lella. 2018. Bioefficacy of Essential Oils and Plant Oils for the Management of Banana Anthracnose-A Major Post-harvest Disease. Int.J.Curr.Microbiol.App.Sci. 7(04): 2359-2365. doi: https://doi.org/10.20546/ijcmas.2018.704.270 